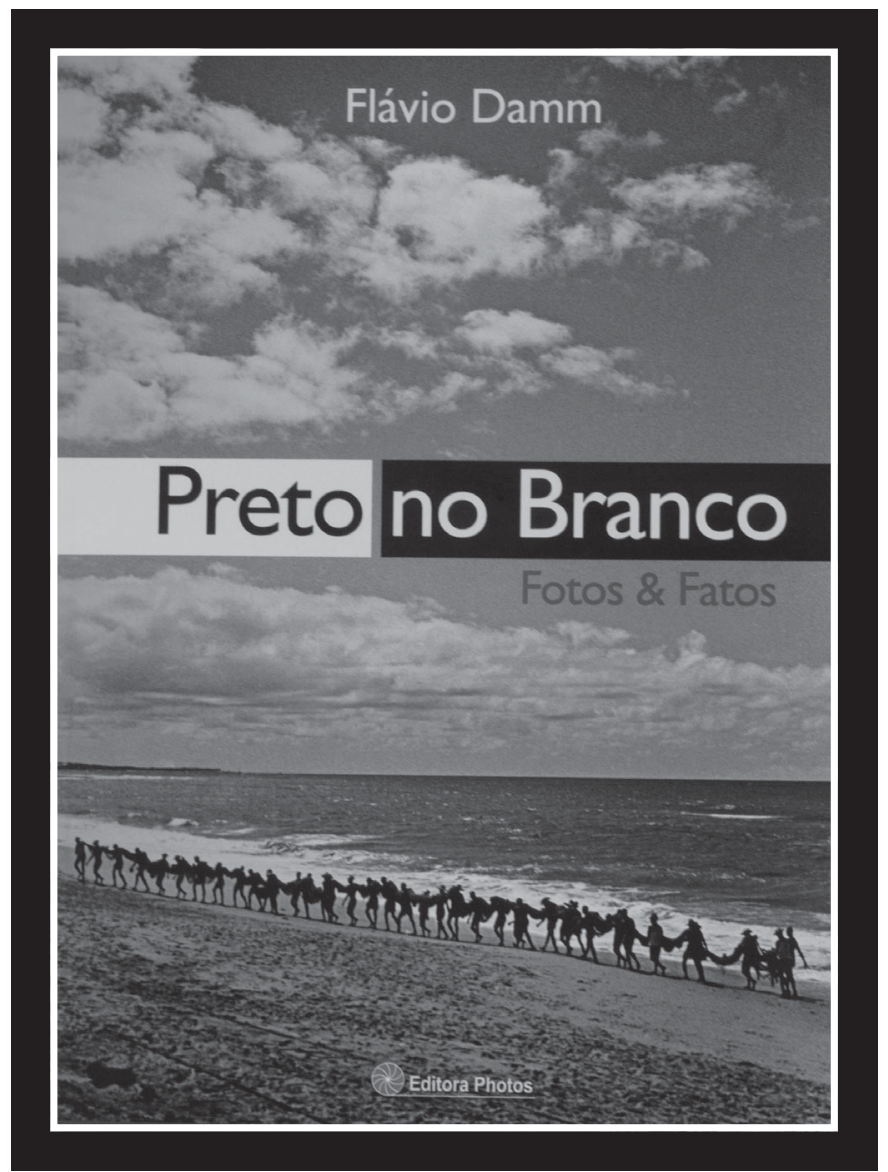

Preto no branco: fotos \& fatos, de Flávio Damm. Balneário Camboriú, Editora Photos, 2008, 139 páginas. 


\section{Flávio Damm: 64 anos de fotojornalismo}

\section{Simonetta Persichetti*}

Flávio Damm começou a fotografar aos 16 anos na Revista, publicada pela Editora Globo em Porto Alegre. Desde então, nunca mais deixou de fotografar. São 64 anos de fotografia, dez dos quais na lendária revista $O$ Cruzeiro.

Além de fotógrafo, Flávio Damm escreve e publica textos e pensatas sobre a fotografia. Tem uma coluna na revista Photos e no portal da mesma revista, sempre abordando temas fotojornalísticos. Fotografa sempre em preto e branco e em suas fotografias é possível reconhecer a estética clássica de fotógrafos como Manuel Álvares Bravo, Robert Doisneau e André Kertéscz.

Parte de suas andanças e fotografias foram reunidas no livro Preto no branco: fotos \& fatos, lançado em setembro de 2008 pela Editora Photos: "Como fotojornalista andei por andar, andei, como diz Dorival Caymmi, cumprindo a pauta da curiosidade por sessenta e quatro anos, descobrindo gente e lugares, ouvindo e fotografando, guardando bons e maus momentos, a vida dos outros caindo na minha rede de pescador de fotos e fatos", escreve no prefácio do livro.

São vinte histórias, vinte fotografias que se completam e complementam. A leitura é deliciosa, como se estivéssemos sentados numa mesa de bar, conversando com ele. Como se ele estivesse nos mostrando suas fotografias e para cada uma relembrasse a história de como foi feita, o que aconteceu, como conseguiu fazer a fotografia mesmo que em alguns momentos o clique parecesse impossível ou

\footnotetext{
${ }^{1}$ Simonetta Persichetti, jornalista e critica de fotografia, é doutora em Psicologia Social pela Pontifícia Universidade Católica de São Paulo e professora do Mestrado em Comunicação da Universidade Estadual de Londrina. Escreve sobre fotografia para $O$ Estado de S. Paulo e coordena a pesquisa e publicação da Coleção Senac de Fotografia. É autora dos livros Imagens da fotografia brasileira I e II.
} 
pelo menos difícil de ser feito. Na sua narrativa - também a narrativa de um país - momentos do cotidiano, históricos, artísticos; as viagens, os encontros e também, porque não, os desencontros.

Flávio Damm também relata como muitas pautas eram decididas na revista $O$ Cruzeiro, como era preciso "correr atrás". As mais interessantes eram as sugeridas pelas cartas dos leitores. Por causa destas missivas foi atrás de histórias surrealistas, em locais distintos, acompanhado de sua Leica, mas também de seu caderno de anotações.

Nesta época o fotógrafo se considerava jornalista e agia como tal. Época em que havia a dupla jornalista/fotorrepórter e as matérias do jornal se resolviam na rua, e não na cadeira de uma redação: “A rua deu-me oportunidade das surpresas contidas neste livro, elas não me pertencem senão pelo momento mágico de terem acontecido na minha frente", afirma.

Não é bem assim. As histórias não aconteciam à sua frente, ele as procurava. Assim foi na viagem à Buenos Aires, durante o governo de Juan Peron, em 1951. Como a revista $O$ Cruzeiro era contra a ditadura peronista, os fotógrafos dos Diários Associados não podiam entrar em território argentino. Flávio Damm não se importou. Financiado pela revista, mas sob risco próprio, embarcou para capital portenha. Ao chegar ao aeroporto mostrou sua credencial da agência Black Star de Nova Iorque. A polícia não acreditou e ele ficou detido várias horas. Liberado, dirigiu-se à embaixada brasileira. A convite desta, compareceu a um jantar com jornalistas brasileiros que o próprio Perón estava oferecendo. Fez inúmeras fotografias. Na saída ainda foi abraçado por Evita Perón: "Em doze horas havia sido preso pelo exército de Perón e abraçado por sua mulher, Evita", escreve. Ele tinha apenas 23 anos!

São histórias como estas pelo mundo e pelo Brasil que fazem do livro de Flávio Damm uma deliciosa história de jornalismo, contada por meio das palavras e das imagens. Só um porém: a péssima 
impressão do livro. Se para o texto tudo bem, para as fotografias é quase um atentado. E isso porque o livro foi publicado por uma editora de fotografia! 